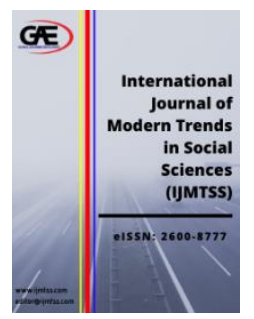

\author{
INTERNATIONAL JOURNAL OF \\ MODERN TRENDS IN \\ SOCIAL SCIENCES \\ (IJMTSS) \\ www.ijmtss.com
}

\title{
A BIBLIOMETRIC ANALYSIS OF 68 YEARS OF RESEARCH ON CHARITABLE GIVING
}

\author{
Aqilah Yaacob $^{1^{*}}$, Gan Jen Ling ${ }^{2}$ \\ 1 School of Management and Marketing, Taylor's University, Malaysia \\ Email: aqilah.yaacob@taylors.edu.my \\ 2 School of Management and Marketing, Taylor's University, Malaysia \\ Email: jenling.gan@taylors.edu.my \\ * Corresponding Author
}

\section{Article Info:}

Article history:

Received date:09.12.2020

Revised date: 21.12 .2020

Accepted date: 05.01.2021

Published date: 03.03.2021

\section{To cite this document:}

Yaacob, A., \& Gan, J. L. (2021). A Bibliometric Analysis of 68 Years of Research on Charitable Giving. International Journal of Modern Trends in Social Sciences, 4 (15), 2142.

DOI: 10.35631/IJMTSS.415003

This work is licensed under CC BY 4.0

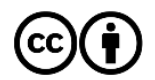

\begin{abstract}
:
This is the first study, to the authors' knowledge, to evaluate and quantify the progress of charitable giving as there is no research on the global trend of charitable giving. This research aimed to retrieve journal articles related to charitable giving over a 68-year time span and suggest new avenues for future research. This study involved a bibliometric analysis from 1,144 publications related to the theme, registered in the Scopus database from 1951 to the recent publication in 2019. The bibliometric procedures examined the research performance and development within the framework of international impact, while VOS Viewer 1.6.11 visualized the overall research trend of charitable giving. The results indicate that the United States is the country with the most publications related to charitable giving. James, R.N. and List, J.A. are the two leading authors in this field based on the total number of publications. Most of the articles published in this field are found in Non-profit and Voluntary Sector Quarterly, Journal of Public Economics, and Voluntas journals. While Journal of Business Research and Journal of Consumer Research are the top two leading CiteScore journals in charitable giving studies. Among the most recent author keywords are crowdfunding, social media, social status, social preferences, emotion, incentives, agency, and laboratory experiment, which demonstrated the current keen interest associated with charitable giving studies. This paper is beneficial for academicians, organizations, and policymakers in understanding the general picture of the field and enables future scholars to see where the study began and trace its shift over time.
\end{abstract}

Keywords:

Bibliometric, Scopus, VOS Viewer, Charitable Giving, Charity 


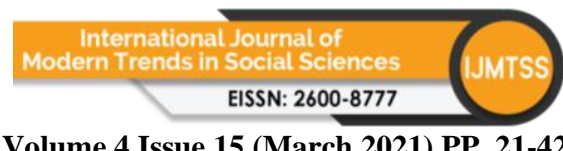

Volume 4 Issue 15 (March 2021) PP. 21-42

DOI 10.35631/IJMTSS.415003

\section{Introduction}

Charitable giving studies has captured interest and attention in recent years as it was recognised as one of the contributors to the success of charitable organisations (or charities). According to Andreoni and Payne (2013), charitable giving is viewed as a market, it is vital for researcher to understand the interactions among the key players in charitable giving such as donors as the suppliers of funds, charitable organisations as demanders of funds, and government as policy interventions. The charity sector has expanded in recent years with an increase in numbers of charities and their charitable spending. However, there are several challenges faced by charities such as increased competition in attracting donors and retaining existing supporters, especially among smaller organisations who are struggling to survive, as well as the nature of fundraising is changing with the rise in the use of social media and plentiful charitable campaigns (Dudman, 2017; Dean, 2020; Bhati and McDonnell, 2020).

Charitable giving or charitable donation is a voluntary contribution in the form of cash, belongings, time, or services made to a charitable organization to assist them in accomplishing its social mission. Research in understanding charitable giving has become a familiar debate among researchers, government bodies and non-profit organisations. Many stakeholders are increasingly becoming more aware of its importance, particularly concerning its role in helping the underprivileged groups and assisting the government and charities in eradicating social issues (Bennett, 2005). Therefore, charitable giving studies provide deeper insights of the dynamic relationship between the haves and the have-nots.

Previous research includes a bibliometric analysis studies of non-profit branding (Sepulcri et al., 2020), corporate volunteering (Dreesbach-Bundy and Scheck, 2017), financial return crowdfunding (Martínez-Climent et al., 2018) and crowdfunding (Zhang et al., 2018). However, to the best of the researchers' knowledge, there is no specific bibliometric analysis done on the current trends and future prospect of charitable giving. Thus, the present study contributes to the existing literature by providing the first bibliometric analysis of the influence of the charitable giving.

This study aims to present a full picture and map the knowledge of previous research on this area. Moreover, this study suggests new avenues for future research using bibliometric analysis techniques depending on Scopus database for the period of 68 years (1951 - 2019). This paper brings a worldwide perspective due to the fact that it analyses and organise large amounts of historical data on charitable giving by identifying the research trend of charitable giving, the top leading journals published in this area, most influential researcher and regions where most publications and citations are taking place. As a result, this research provides new insight for future scholars in examining upcoming directions of charitable giving studies.

\section{Methods}

By collecting bibliographic data from other published papers in the particular discipline, bibliometric analysis is performed by analysing the scholars' thinking through writing and citation (Zupic and Carter, 2015). By performing bibliometric analysis, it can be helpful to explore the topic of interest in particular discipline hence providing future directions for researchers (Khudzari et al., 2018). To differentiate review paper and bibliometric analysis, the latter provides further information on the past performance of publications in particular disciplines and illustrates the trend of discipline. 


\section{Searching Strategy}

The data mining for the bibliometric analysis was performed from $25^{\text {th }}$ to $27^{\text {th }}$ September 2020, via Scopus database. To do this, the authors had set key theme for the analysis. The main theme of this analysis is "charitable behaviour", "charitable giving", and "donor behaviour" as the keywords to be found in abstract and title for the purpose to analyse their trend globally. In the process of searching, the authors sorted the articles according to years (oldest to latest), where the oldest paper was in 1951, while the latest is 2019. In order to ensure that the authors are able to retrieve all relevant articles that were researched about charitable behaviour, the authors were aware that the spelling of "behaviour" could have different spelling in different nations, that is "behavior". Hence, in developing the query string for this bibliometric analysis, the query string was as: ( TITLE-ABS-KEY ( "charitable giving" ) OR TITLE-ABS-KEY ( "charitable behavi*r" ) OR TITLE-ABS-KEY ( "donor behavi*r" ) AND DOCTYPE ( ar ) AND PUBYEAR > 1951 AND PUBYEAR < 2019 AND ( LIMIT-TO ( SRCTYPE, " $j "$ ) ). By inserting the asterisk, it can help the authors to retrieve all the articles that used "behavior" and "behaviour".
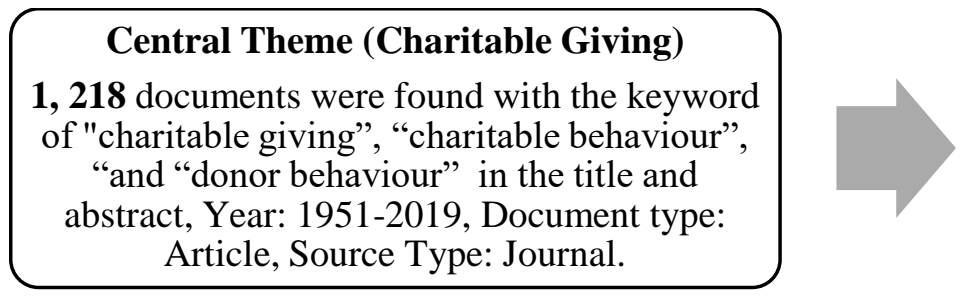

\section{Excluding Non-empirical Articles}

1,144 documents remained after excluding 74 non-empirical articles, identified by the title and abstract.

Source: This Study

\section{Figure 1: Searching Strategy}

A total of 1, 218 documents was retrieved from the query string. However, the 1, 218 documents have included non-empirical paper, that is irrelevant to this analysis. Therefore, in order to exclude non-empirical papers in the query string, the authors added keywords, such as "progress", "review", "highlight", and "revisit" in the next query string. A total of 74 nonempirical papers was found after screening the new query string. The Scopus article identifier (EIDs) of the 74 articles were jotted down and included in the next query string that excluded the non-empirical papers. By excluding the non-empirical papers, 1, 144 documents were retrieved. By retrieving this data, the bibliometric analysis can be started by analysing the bibliometric information. The search strategy process was indicated in Figure 1, while the query strings were listed in Table 1.

Table 1: Search Strategies and Query Strings

\begin{tabular}{|l|l|l|l|}
\hline \multicolumn{1}{|c|}{ Items } & Theme & \multicolumn{1}{|c|}{ Search for: } & \multicolumn{1}{c|}{ Query Strings } \\
\hline i. & Central & Charitable Giving articles & $\begin{array}{l}\text { (TITLE-ABS-KEY ("charitable behavi*r") } \\
\text { OR ("charitable } \\
\text { giving") OR TITLE-ABS-KEY ( "donor } \\
\text { behavi*r" ) AND DOCTYPE ( ar ) AND } \\
\text { PUBYEAR > 1951 AND PUBYEAR } \\
\text { 2019 AND ( LIMIT-TO ( SRCTYPE , "j" ) } \\
\text { ii. }\end{array}$ \\
\hline Central & $\begin{array}{l}\text { Non-empirical articles in } \\
\text { (i) }\end{array}$ & $\begin{array}{l}\text { (TITLE-ABS ("charitable behavi*r") OR } \\
\text { TITLE-ABS-KEY ("charitable giving") }\end{array}$ \\
\hline
\end{tabular}




\begin{tabular}{|c|c|c|c|}
\hline & & & $\begin{array}{l}\text { OR TITLE-ABS-KEY ( "donor behavi*r" } \\
\text { )) AND (TITLE ("recent" OR progress OR } \\
\text { review OR critical OR revisit OR advance } \\
\text { OR development OR highlight OR } \\
\text { perspective OR prospect OR trends OR } \\
\text { bibliometric OR scientometric) OR (ABS } \\
\text { (progress OR review OR bibliometric OR } \\
\text { scientometric )) ) }\end{array}$ \\
\hline iii. & Central & $\begin{array}{l}\text { Charitable Giving without } \\
\text { non-empirical articles }\end{array}$ & $\begin{array}{l}\text { (TITLE-ABS ("charitable behavi*r") OR } \\
\text { TITLE-ABS-KEY ("charitable giving") } \\
\text { OR TITLE-ABS-KEY ( "donor behavi*r" } \\
\text { )) AND DOCTYPE (ar) AND PUBYEAR } \\
>1951 \text { AND PUBYEAR < } 2019 \text { AND } \\
\text { NOT EID (insert EID of review articles } \\
\left.\text { here }^{*}\right) \text { AND (LIMIT-TO (SRCTYPE, "j")) }\end{array}$ \\
\hline
\end{tabular}

Source: This Study

\section{Bibliometric Map}

With the assistance of VOS Viewer version 1.6.11, bibliometric maps were created and visualized in this bibliometric analysis. Via the visualization function in VOS Viewer, it can assist this paper to present objects of interest, which includes author keywords, and coauthorship analysis. In the visualized pictures that are retrieved from VOS Viewer, each item in the picture will be connected with a line to show the strength of the linkage between items, which is known as strength value. The higher the strength value, the stronger the linkage between connected items (Khudzari et al., 2018). Co-authorship analysis helps the readers to understand the number of publications between the linked countries, while author keywords analysis provides the understanding of the number of researches that linked two keywords simultaneously (Van Eck and Waltman, 2018).

\section{Co-Authorship Analysis}

In the co-authorship analysis, a total of 66 nations were affiliated with 156 authors. The affiliated nations were clustered into eight regions, which are United Kingdom, America, Oceania, Asia, Eurasia, Europe, Middle East, and Africa.

\section{Analysis of Co-Occurrence}

The co-occurrence analysis consists of author keywords and the exclusion of Scopus indexed keywords with a total of 74 keywords from 1,144 articles. Before importing all the author keywords into VOSviewer, the authors created a thesaurus file to prevent any identical keywords from repeating. This is done by screening and grouping the synonymic keywords. For instance, charitable contributions and charitable donations have similar meaning, therefore the authors re-labelled it as 'charitable giving'.

In order to produce the output of analysis for author keywords, this study set the minimum of five occurrences. The VOSviewer was then adjusted to visualisation setting to examine the strength of connection among the author keywords, number of occurrences, and average publications of year. 


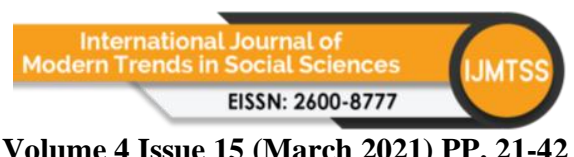

Volume 4 Issue 15 (March 2021) PP. 21-42

\section{Results and Discussion}

DOI 10.35631/IJMTSS.415003

\section{Research Growth and Subject Area}

A total of 1, 144 research articles were published in 68 years. The trend of publication is illustrated in Figure 2. The first charitable giving research was in 1951 by Duquette, N.J., and there was zero publication until the year of 1962. From 1998 onwards, the publication rate has been steadily increasing. This indicated that the research of charitable giving has been active since 1998. After that, the growth rate gradually increased in 2008, where the amount was almost three times more than the rate in 1998. From 2008 to 2019, the publication rate increased progressively and significantly, hence it is believed that the attention of charitable giving could be increasing from one year to another. As of 2019, only 9.3\% (106 articles) are open access articles, therefore it is recommended that more journal articles should have public access to readers to increase the rate of readability.

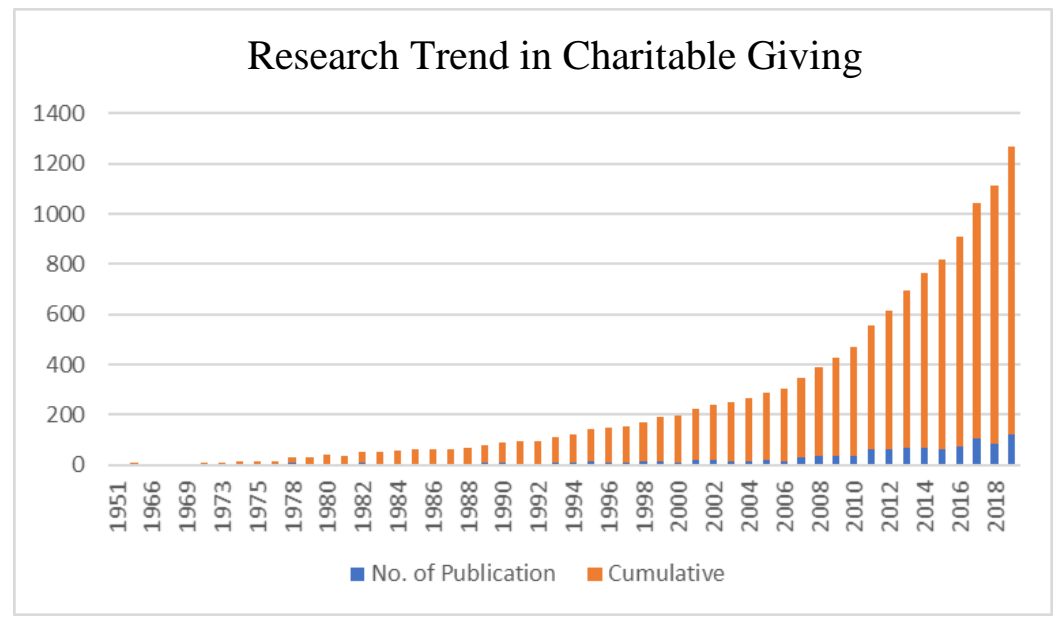

Source: This Study

Figure 2: Research Trend in Charitable Giving

The trend of charitable giving has been receiving attention from the scholars of different disciplines. As retrieved from Scopus database, a total of 26 subject areas discussed about charitable giving. Among the 26 subject areas, the top five subject areas are known as Social Sciences (423 articles), Economics, Econometrics, and Finance (397 articles), Business, Management and Accounting (339 articles), Psychology (157 articles), and Medicine (98 articles). Although the main subject areas are focusing on Social Sciences and Business Studies, interestingly it was found that charitable giving could be involved in multidisciplinary area as well. For example, charitable giving was discussed in the discipline of Agricultural and Biological Sciences (24 articles), and even Chemistry (54 articles). Hence, charitable giving discussion is not only vital in Social Sciences and Business Studies, but it also plays certain roles in Sciences discipline as well.

\section{Top Productive Journals Analysis}

A total of ten productive journals was indicated in Table 2, where they are from five publishers. The top three journals that were leading the list are from Non-profit and Voluntary Sector Quarterly, Journal of Public Economics, and Voluntas. Out of five publishers, Elsevier had the highest number of journals, where 4/10 journals are from this publisher. The remaining journals are from Springer Nature (3/10), SAGE (1/10), Taylor and 
Francis (1/10), and Wiley-Blackwell (1/10). From the list, it can be seen that majority (90\%) of the journals were in Quartile 1 (Q1), while only one journal was in Quartile 3 (Q3).

Non-profit and Voluntary Sector Quarterly was the most productive journal in publishing charitable giving articles, where 59 journal articles were published, owning 5.2\% of the total publication $(1,144)$ of charitable giving. Followed by Journal of Public Economics (53, 4.6\%), Voluntas (38, 3.3\%), Journal of Economic Behaviour and Organization (25, 2.2\%), and Journal of Behavioural and Experimental Economics (20, 1.7\%). Among the top productive journals, Journal of Public Economics had the most citations with a total of 1, 422, followed by Non-profit and Voluntary Sector Quarterly that had second highest citation amount, which was 1, 184. The journal article that had the highest citation amount was under Journal of Business Ethics, which was 221 citations.

Table 2: Top Ten Journals

\begin{tabular}{|c|c|c|c|c|c|c|c|c|}
\hline Rank & Journal & Quartile & $\begin{array}{l}\text { TP } \\
(\%)\end{array}$ & TC & $\begin{array}{c}\text { CiteScore } \\
2019\end{array}$ & $\begin{array}{c}\text { The most cited } \\
\text { article (Reference) }\end{array}$ & $\begin{array}{l}\text { Times } \\
\text { cited }\end{array}$ & Publisher \\
\hline 1 & $\begin{array}{l}\text { Non-profit } \\
\text { and } \\
\text { Voluntary } \\
\text { Sector } \\
\text { Quarterly }\end{array}$ & Q1 & $\begin{array}{l}59 \\
(5.2 \\
\%)\end{array}$ & $\begin{array}{l}1, \\
18 \\
4\end{array}$ & 3.6 & $\begin{array}{l}\text { Gender differences } \\
\text { in the correlates of } \\
\text { volunteering and } \\
\text { charitable giving } \\
\text { (Einolf, 2011) }\end{array}$ & 112 & SAGE \\
\hline 2 & $\begin{array}{l}\text { Journal of } \\
\text { Public } \\
\text { Economics }\end{array}$ & Q1 & $\begin{array}{l}53 \\
(4 . \\
6 \%)\end{array}$ & $\begin{array}{l}1, \\
42 \\
2\end{array}$ & 3.5 & $\begin{array}{l}\text { Rebate versus } \\
\text { matching: Does how } \\
\text { we subsidize } \\
\text { charitable } \\
\text { contributions matter? } \\
\text { (Eckel, \& Grossman, } \\
\text { 2003) }\end{array}$ & 151 & Elsevier \\
\hline 3 & Voluntas & Q1 & $\begin{array}{l}38 \\
(3.3 \\
\%)\end{array}$ & $\begin{array}{l}57 \\
1\end{array}$ & 2.9 & $\begin{array}{l}\text { Social participation } \\
\text { and charitable } \\
\text { giving: } \\
\text { multivariate analysis } \\
\text { (Schervish, } \quad \& \\
\text { Havens, 1997) }\end{array}$ & 117 & $\begin{array}{l}\text { Springer } \\
\text { Nature }\end{array}$ \\
\hline 4 & $\begin{array}{l}\text { Journal of } \\
\text { Economic } \\
\text { Behaviour } \\
\text { and } \\
\text { Organizatio } \\
\mathrm{n}\end{array}$ & Q1 & $\begin{array}{l}25 \\
(2.2 \\
\%)\end{array}$ & $\begin{array}{l}22 \\
4\end{array}$ & 2.5 & $\begin{array}{l}\text { Effects of the price } \\
\text { of charitable giving: } \\
\text { Evidence from an } \\
\text { online crowdfunding } \\
\text { platform (Meer, } \\
2014 \text { ) }\end{array}$ & 55 & Elsevier \\
\hline 5 & $\begin{array}{l}\text { Journal of } \\
\text { Behavioura } \\
1 \text { and } \\
\text { Experiment } \\
\text { al } \\
\text { Economics }\end{array}$ & Q1 & $\begin{array}{l}20 \\
(1.7 \\
\%)\end{array}$ & 71 & 1.9 & $\begin{array}{l}\text { A field experiment } \\
\text { on directed giving at } \\
\text { a public university } \\
\text { (Eckel, Herberich, \& } \\
\text { Meer, 2017) }\end{array}$ & 14 & Elsevier \\
\hline 6 & Journal of & Q3 & 18 & 11 & 1.3 & An examination of & 15 & Taylor \& \\
\hline
\end{tabular}


Volume 4 Issue 15 (March 2021) PP. 21-42

DOI 10.35631/IJMTSS.415003

\begin{tabular}{|c|c|c|c|c|c|c|c|c|}
\hline & $\begin{array}{l}\text { Non-profit } \\
\text { and Public } \\
\text { Sector } \\
\text { Marketing }\end{array}$ & & $\begin{array}{l}(1.6 \\
\%)\end{array}$ & 7 & & $\begin{array}{l}\text { helping behaviour- } \\
\text { some evidence from } \\
\text { Australia (Polonsky, } \\
\text { Shelley, \& Voola, } \\
\text { 2002) }\end{array}$ & & Francis \\
\hline 7 & $\begin{array}{l}\text { Journal of } \\
\text { Business } \\
\text { Ethics }\end{array}$ & Q1 & $\begin{array}{l}16 \\
(1.4 \\
\%)\end{array}$ & $\begin{array}{l}1, \\
10 \\
1\end{array}$ & 7.0 & $\begin{array}{l}\text { Women on } \\
\text { Corporate Boards of } \\
\text { Directors and their } \\
\text { Influence } \\
\text { Corporate } \\
\text { Philanthropy } \\
\text { (Williams, 2003) }\end{array}$ & 221 & $\begin{array}{l}\text { Springer } \\
\text { Nature }\end{array}$ \\
\hline 8 & $\begin{array}{l}\text { Journal of } \\
\text { Economic } \\
\text { Psychology }\end{array}$ & Q1 & $\begin{array}{l}16 \\
(1.4 \\
\%)\end{array}$ & $\begin{array}{l}17 \\
9\end{array}$ & 3.4 & $\begin{array}{l}\text { Developing, } \\
\text { exploring, and } \\
\text { validating a typology } \\
\text { of private } \\
\text { philanthropic } \\
\text { decision making } \\
\text { (Supphellen \& } \\
\text { Nelson, 2001) }\end{array}$ & 33 & Elsevier \\
\hline 9 & $\begin{array}{l}\text { Non-profit } \\
\text { Manageme } \\
\text { nt and } \\
\text { Leadership }\end{array}$ & Q1 & $\begin{array}{l}16 \\
(1.4 \\
\%)\end{array}$ & $\begin{array}{l}13 \\
3\end{array}$ & 2.9 & $\begin{array}{l}\text { Keeping up with the } \\
\text { Joneses: The } \\
\text { relationship of } \\
\text { perceived descriptive } \\
\text { social norms, social } \\
\text { information, and } \\
\text { charitable giving } \\
\text { (Croson, Handy, \& } \\
\text { Shang, 2009) }\end{array}$ & 37 & $\begin{array}{l}\text { Wiley- } \\
\text { Blackwell }\end{array}$ \\
\hline 10 & $\begin{array}{l}\text { Experiment } \\
\text { al } \\
\text { Economics }\end{array}$ & Q1 & $\begin{array}{l}13 \\
(1.1 \\
\%)\end{array}$ & $\begin{array}{l}56 \\
4\end{array}$ & 3.9 & $\begin{array}{l}\text { Do people behave in } \\
\text { experiments as in the } \\
\text { field?-Evidence from } \\
\text { donations (Benz \& } \\
\text { Meier, 2008) }\end{array}$ & 149 & $\begin{array}{l}\text { Springer } \\
\text { Nature }\end{array}$ \\
\hline
\end{tabular}

Source: Compiled by This Study. Note: TP=Total Publication; TC=Total Citation

As referring to CiteScore 2019, only one journal scored more than 5.0, which was Journal of Business Ethics (CiteScore 7.0). Journal of Business Ethics scored the highest CiteScore among the top 10 journals, while Journal of Non-profit and Public Sector Marketing scored the lowest (CiteScore 1.3). The CiteScore was viewed as one of the criteria for future researchers to publish their research. Hence, in order to assist the readers to choose the suitable journals, a list of top CiteScore journals was prepared in Table 3. 
Table 3: The Leading CiteScore Journals in Charitable Giving Studies (Minimum Ten Research Articles)

\begin{tabular}{|c|c|c|c|c|}
\hline Rank & Name of Journal & $\begin{array}{l}\text { CiteScore } \\
\text { in } 2019\end{array}$ & Publisher & $\begin{array}{c}\text { Amount of } \\
\text { Publicatio } \\
\text { n }\end{array}$ \\
\hline 1 & Journal of Business Research & 8.9 & Elsevier & 10 \\
\hline 2 & Journal of Consumer Research & 8.5 & $\begin{array}{l}\text { Oxford University } \\
\text { Press }\end{array}$ & 11 \\
\hline 3 & Journal of Business Ethics & 7.0 & Springer Nature & 16 \\
\hline 4 & Plos One & 5.2 & $\begin{array}{l}\text { Public Library of } \\
\text { Science }\end{array}$ & 10 \\
\hline 5 & Transfusion & 4.9 & Wiley-Blackwell & 13 \\
\hline 6 & Experimental Economics & 3.9 & Springer Nature & 13 \\
\hline 7 & $\begin{array}{l}\text { Nonprofit and Voluntary } \\
\text { Quarterly }\end{array}$ & 3.6 & SAGE & 59 \\
\hline 8 & Journal of Public Economics & 3.5 & Elsevier & 53 \\
\hline 9 & Journal of Economic Psychology & 3.4 & Elsevier & 16 \\
\hline 10 & Voluntas & 2.9 & Springer Nature & 38 \\
\hline 11 & Nonprofit Management and Leadership & 2.9 & Wiley-Blackwell & 16 \\
\hline 12 & $\begin{array}{l}\text { Journal of Economic Behavior and } \\
\text { Organization }\end{array}$ & 2.5 & Elsevier & 25 \\
\hline 13 & Economics Letters & 2.1 & Elsevier & 11 \\
\hline 14 & $\begin{array}{l}\text { Journal of Behavioral and Experimental } \\
\text { Economics }\end{array}$ & 1.9 & Elsevier & 20 \\
\hline 15 & Applied Economics & 1.9 & Taylor \& Francis & 11 \\
\hline 16 & $\begin{array}{l}\text { Journal of Nonprofit and Public Sector } \\
\text { Marketing }\end{array}$ & 1.3 & Taylor \& Francis & 18 \\
\hline 17 & $\begin{array}{l}\text { International Journal of Nonprofit and } \\
\text { Voluntary Sector Marketing }\end{array}$ & 1.1 & Wiley-Blackwell & 12 \\
\hline
\end{tabular}

Source: Compiled by This Study

\section{Top Nations, Collaboration, and Institutions Analysis}

Table 4 indicated the top nations that published the work of charitable giving at the global level. More than $50 \%$ of the publications were led by the United States (US), followed by United Kingdom (UK). This indicated that both countries are the main contributors in the work of charitable giving. US had the highest number of publications with 592 articles, covered $51 \%$ of all charitable giving publications in the global level. Based on the 151 articles, UK was ranked as the top two productive nation in charitable giving publication.

Table 4: Top Nations, Collaboration, and Institutions

\begin{tabular}{|l|l|l|l|l|l|}
\hline Rank & \multicolumn{1}{|c|}{ Country } & \multicolumn{1}{|c|}{ TPC } & SCP (\%) & \multicolumn{1}{|c|}{ Productive Academic Institution } & TPI \\
\hline 1 & United States & 592 & $81.8 \%$ & University of Pennsylvania & 23 \\
\hline 2 & United Kingdom & 151 & $67.5 \%$ & University College London & 10 \\
\hline 3 & Germany & 65 & $46.2 \%$ & University of Cologne & 4 \\
\hline 4 & Canada & 60 & $43.3 \%$ & The University of British Columbia & 6 \\
\hline 5 & Australia & 45 & $57.8 \%$ & $\begin{array}{l}\text { Queensland University of Technology } \\
\text { QUT }\end{array}$ & 7 \\
\hline 6 & China & 43 & $51.2 \%$ & Beijing Normal University & 4 \\
\hline
\end{tabular}


DOI 10.35631/IJMTSS.415003

\begin{tabular}{|l|l|l|l|l|l|}
\hline 7 & Netherlands & 40 & $52.5 \%$ & Vrije Universiteit Amsterdam & 15 \\
\hline 8 & Italy & 28 & $46.4 \%$ & Consiglio Nazionale delle Ricerche & 7 \\
\hline 9 & Sweden & 22 & $36.3 \%$ & Linköpings universitet & 8 \\
\hline 10 & France & 20 & $60.0 \%$ & ESSEC Business School & 4 \\
\hline
\end{tabular}

Source: Compiled by This Study. Note: TPC=Total Publications of The Country; SCP=Single-Country Publications; TPI=Total Publications of The Organization

In Table 4, among the top productive nations, only six nations scored more than $50 \%$ single country publications (SCP value), namely United States (81.8\%), United Kingdom (67.5\%), Australia (57.8\%), China (51.2\%), Netherlands (52.5\%), and France (60.0\%). This result indicated that these countries had more collaborations with other countries at a global level. In the list, Sweden scored the lowest SCP (36.3\%). The SCP value could be improved by working together with international institutions which can act as a good strategy to increase the SCP value.

Furthermore, there are two universities were ranked as the top 100 best institutions in World University Rankings in 2020 (THE, 2020), which were University of Pennsylvania (15 $\left.{ }^{\text {th }}\right)$, and The University of British Columbia $\left(51^{\mathrm{st}}\right)$. This brings a meaning that the topic of charitable giving received attention from the top institutions at the global level. A list of top 50 productive nations was prepared in Table 5.

Table 5: The Top 50 Most Productive Institutions in Charitable Giving Research

\begin{tabular}{|l|l|l|l|}
\hline Rank & \multicolumn{1}{|c|}{ Institution } & \multicolumn{1}{c|}{$\begin{array}{c}\text { No of } \\
\text { Publications }\end{array}$} & \multicolumn{1}{c|}{ Country } \\
\hline 1 & University of Pennsylvania & 23 & US \\
\hline 2 & Indiana University Bloomington University-Purdue University & 21 & US \\
\hline 3 & $\begin{array}{l}\text { Indiana US } \\
\text { Indianapolis }\end{array}$ & 18 & US \\
\hline 4 & Texas A\&M University & 15 & Netherlands \\
\hline 5 & Vrije Universiteit Amsterdam & 15 & US \\
\hline 6 & National Bureau of Economic Research & 15 & US \\
\hline 7 & The University of Chicago & 12 & US \\
\hline 8 & Yale University & 12 & US \\
\hline 9 & Harvard University & 12 & US \\
\hline 10 & University of Michigan, Ann Arbor & 11 & US \\
\hline 11 & University of Georgia & 10 & India \\
\hline 12 & National Institute of Technology Kurukshetra & 10 & US \\
\hline 13 & University College London & 10 & US \\
\hline 14 & University of California, Berkeley & 10 & Netherlands \\
\hline 15 & University of California, San Diego & 9 & US \\
\hline 16 & Universiteit van Amsterdam & 9 & Sweden \\
\hline 17 & Duke University & 9 & UK \\
\hline 18 & Linköpings universitet & 9 & US \\
\hline 19 & University of Kent & 9 & \\
\hline 20 & University at Albany & 9 & US \\
\hline 21 & Wharton School of the University & \\
\hline
\end{tabular}


DOI 10.35631/IJMTSS.415003

\begin{tabular}{|c|c|c|c|}
\hline & Pennsylvania & & \\
\hline 22 & University of Memphis & 9 & US \\
\hline 23 & Columbia University in the City of New York & 9 & US \\
\hline 24 & University of Wisconsin-Madison & 9 & US \\
\hline 25 & $\begin{array}{l}\text { London School of Economics and Political } \\
\text { Science }\end{array}$ & 8 & UK \\
\hline 26 & The University of Manchester & 8 & UK \\
\hline 27 & University of Oregon & 8 & US \\
\hline 28 & St. Cloud State University & 8 & US \\
\hline 29 & Texas Tech University & 8 & US \\
\hline 30 & DePaul University & 8 & US \\
\hline 31 & University of Southern California & 8 & US \\
\hline 32 & Wirtschaftsuniversität Wien & 7 & Austria \\
\hline 33 & Princeton University & 7 & US \\
\hline 34 & Queensland University of Technology QUT & 7 & Australia \\
\hline 35 & University of Nottingham & 7 & UK \\
\hline 36 & Göteborgs Universitet & 7 & Sweden \\
\hline 37 & Harvard Business School & 7 & US \\
\hline 38 & Consiglio Nazionale delle Ricerche & 7 & Italy \\
\hline 39 & University of Warwick & 7 & UK \\
\hline 40 & University of Southampton & 7 & UK \\
\hline 41 & University of Bath & 7 & UK \\
\hline 42 & The University of Queensland & 7 & Australia \\
\hline 43 & London Metropolitan University & 6 & UK \\
\hline 44 & The Ohio State University & 6 & US \\
\hline 45 & Samford University & 6 & US \\
\hline 46 & Brigham Young University & 6 & US \\
\hline 47 & Utrecht University & 6 & Netherlands \\
\hline 48 & The University of Texas at Dallas & 6 & US \\
\hline 49 & The University of British Columbia & 6 & Canada \\
\hline 50 & Georgia State University & 6 & US \\
\hline
\end{tabular}

Source: Compiled by This Study

With the assistance of VOS Viewer, Figure 3 indicated the analysis of nations. The figure indicated that the stronger the relationship between two nations, the nations will be located nearer to each other, and the line will be thicker in VOS Viewer visualization (Khudzari et al., 2018). In the research area of charitable giving, America was the country with the highest publication rate, followed by United Kingdom. The co-authorship analysis showed that United States was the nation with the highest number of affiliations (29 links, 126 coauthorship), then followed by United Kingdom (27 links, 74 co-authorship), Germany (24 links, 54 co-authorship), Italy (16 links, 25 co-authorship, and others. 
Source: This Study

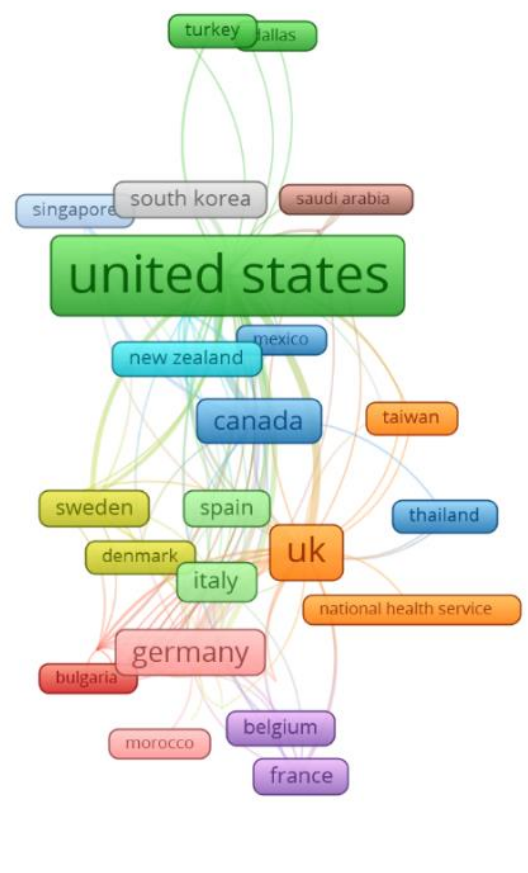

Figure 3: Co-authorship Bibliometric Analysis

The analysis revealed that only $10 \%$ of the nations had more than 10 international collaborative publications. In addition to that, a total of 16 nations were not associated with any international nation in publishing charitable giving articles, for example Chile, Egypt, Iran, Indonesia, Finland, and others. It is suggested that the 16 nations could collaborate by increasing the number of international students in universities, diverse working culture, improving the funding of research, and encouraging international collaborative research climate at respective working places. For example, as retrieved from Scopus database, the ranking indicated that National Science Foundation from the United States was the first leading funding sponsor, hence United States was the first leading nation in publishing charitable giving research articles.

\section{Most Productive and Highly Cited Authors}

Table 6 indicated the top ten productive scholars in the charitable giving research area, who currently affiliated to four countries, namely United States (7), United Kingdom (1), India (1), and Netherlands (1). The top 10 prominent scholars' first publication ranged between from the year of 1965 to 2007, in which majority (90\%) of them were the first author, and only one of them was second author.

The leading three authors were from United States (2) and India (1). The first leading author, James, R.N. was from Texas Tech University, Lubbock, United States, with a total of 15 publications since 2007, 261 citations, and with 8 h-index. Followed by List, J.A. from The University of Chicago, United States, with a total of 11 published works since 1996, with 63 h-index. While Syamal, A. was the third leading author, with a total publication of nine articles, with $17 \mathrm{~h}$-index and 1,041 total citation.

List, J. A's owned the highest citation number, which was 16,069. Interestingly, Eckel, C.C who was ranked as $10^{\text {th }}$ leading author, he received the second highest citation of 5,493. Copyright $\odot$ GLOBAL ACADEMIC EXCELLENCE (M) SDN BHD - All rights reserved 
Authors such as Sargeant, A. (5 $5^{\text {th }}$ leading author) and Bekkers, R. ( $8^{\text {th }}$ leading author) also received high citation of 1,471 and 1,966, respectively. Figure 2 showed that the trend of charitable giving started to increase since 2008, which was a year after the first leading author published his research work. Hence, it can be seen that the leading authors contributed to the trend of research progress.

Table 6: Top Authors

\begin{tabular}{|c|c|c|c|c|c|c|c|c|}
\hline Rank & Author & $\begin{array}{c}\text { ID of } \\
\text { Author in } \\
\text { Scopus }\end{array}$ & $\begin{array}{c}\text { First } \\
\text { publication } \\
\text { year* }\end{array}$ & $\mathbf{T P}$ & $\begin{array}{c}\text { h- } \\
\text { index }\end{array}$ & TC & $\begin{array}{c}\text { Current } \\
\text { Affiliation }\end{array}$ & Country \\
\hline 1 & $\begin{array}{l}\text { James, } \\
\text { R.N. }\end{array}$ & 16304524400 & $2007 a$ & 15 & 8 & 261 & $\begin{array}{l}\text { Texas Tech } \\
\text { University, } \\
\text { Lubbock, } \\
\text { United } \\
\text { States }\end{array}$ & US \\
\hline 2 & List, J.A. & 26643272500 & $1996 a$ & 11 & 63 & $\begin{array}{l}16, \\
069\end{array}$ & $\begin{array}{l}\text { The } \\
\text { University } \\
\text { of Chicago, } \\
\text { Chicago, } \\
\text { United } \\
\text { States }\end{array}$ & US \\
\hline 3 & $\begin{array}{l}\text { Syamal, } \\
\text { A. }\end{array}$ & 6701488912 & $1965 b$ & 9 & 17 & $\begin{array}{l}1, \\
041\end{array}$ & $\begin{array}{l}\text { School of } \\
\text { Coordination } \\
\text { Chemistry, } \\
\text { Mumbai, } \\
\text { India }\end{array}$ & India \\
\hline 4 & $\begin{array}{l}\text { Einolf, } \\
\text { C.J. }\end{array}$ & 16315834200 & $2007 a$ & 8 & 13 & 536 & $\begin{array}{l}\text { Northern } \\
\text { Illinois } \\
\text { University, } \\
\text { DeKalb, } \\
\text { United } \\
\text { States }\end{array}$ & US \\
\hline 5 & $\begin{array}{l}\text { Sargeant, } \\
\text { A. }\end{array}$ & 7006290852 & $1995 a$ & 8 & 23 & 1,471 & $\begin{array}{l}\text { Plymouth } \\
\text { Business } \\
\text { School, } \\
\text { Plymouth, } \\
\text { United } \\
\text { Kingdom }\end{array}$ & UK \\
\hline 6 & $\begin{array}{l}\text { Wiepking, } \\
\text { P. }\end{array}$ & 56614549600 & $2005 a$ & 8 & 12 & 864 & $\begin{array}{l}\text { Indiana } \\
\text { University- } \\
\text { Purdue } \\
\text { University } \\
\text { Indianapolis, } \\
\text { Indianapolis, } \\
\text { United } \\
\text { States }\end{array}$ & US \\
\hline 7 & $\begin{array}{l}\text { Yörük, } \\
\text { B.K. }\end{array}$ & 35618914700 & $2003 a$ & 8 & 10 & 358 & $\begin{array}{l}\text { University at } \\
\text { Albany, }\end{array}$ & US \\
\hline
\end{tabular}




\begin{tabular}{|c|c|c|c|c|c|c|c|c|}
\hline & & & & & & & $\begin{array}{l}\text { Albany, } \\
\text { United } \\
\text { States }\end{array}$ & \\
\hline 8 & $\begin{array}{l}\text { Bekkers, } \\
\text { R. }\end{array}$ & 8637219300 & $2003 a$ & 7 & 19 & 1,966 & $\begin{array}{l}\text { Vrije } \\
\text { Universiteit } \\
\text { Amsterdam, } \\
\text { Amsterdam, } \\
\text { Netherlands }\end{array}$ & Netherlands \\
\hline 9 & $\begin{array}{l}\text { Brooks, } \\
\text { A.C. }\end{array}$ & 7202570671 & $1997 \mathrm{a}$ & 7 & 17 & 914 & $\begin{array}{l}\text { American } \\
\text { Enterprise } \\
\text { Institute, } \\
\text { Washington, } \\
\text { D.C., United } \\
\text { States }\end{array}$ & US \\
\hline 10 & $\begin{array}{l}\text { Eckel, } \\
\text { C.C. }\end{array}$ & 7003583590 & $1985 a$ & 7 & 34 & 5,493 & $\begin{array}{l}\text { Texas A\&M } \\
\text { University, } \\
\text { College } \\
\text { Station, } \\
\text { United } \\
\text { States }\end{array}$ & US \\
\hline
\end{tabular}

Source: This Study. Note: $a=F i r s t$ Author; $b=$ Second Author; $c=$ Third Author and Above; TP=Total Publication; $\mathrm{TC}=$ Total Citation.

\section{Author Keywords}

The authors documented 74 author keywords, where 26\% (19 author keywords) were used for five times, 15\% (11 author keywords) were used for six times, 7\% (5 author keywords) were used for seven times, $8 \%$ (6 author keywords) were used for eight times, 3\% (2 author keywords) were used for nine times, while $42 \%$ (31 author keywords) were used for more than ten times.

In order to avoid identical keywords, the researcher created a thesaurus file in which similar author keywords were re-labelled. As a result, there was a total of 51 author keywords (minimum of five occurrences) generated from the new analysis.

\section{Concept and Terminology}

The analysis of the author keywords co-occurrences suggested that 'charitable giving' was the most frequently used keywords in previous studies. There were 409 occurrences and 48 links to other related keywords as shown in Figure 4. 


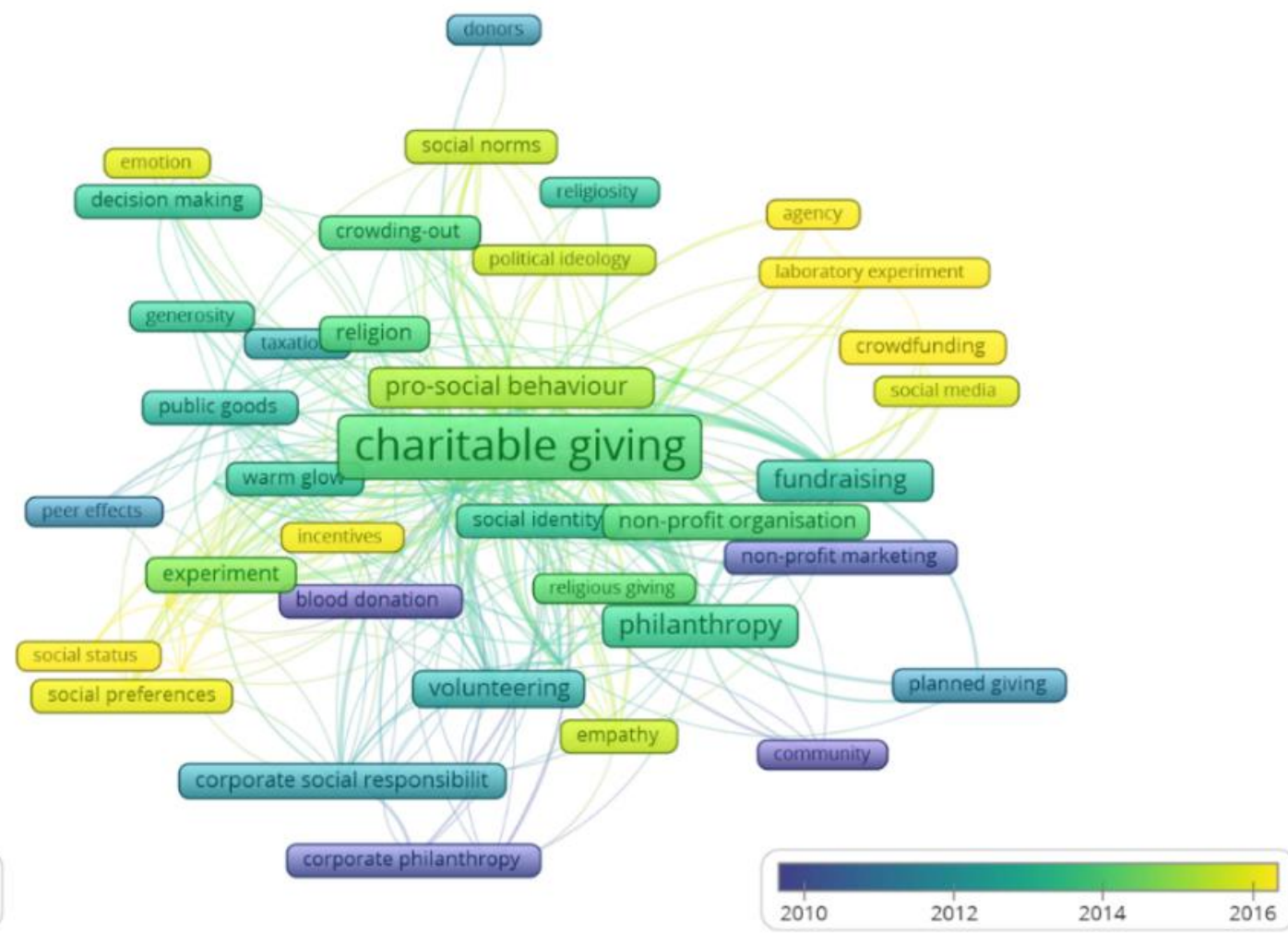

Figure 4: The Bibliometric Map of Author Keywords (Minimum Occurrences: 5) Source: This Study

There were several author keywords often used in relation to charitable giving studies such as 'philanthropy' and 'altruism'. For instances, 'philanthropy' is the second highest occurrences after 'charitable giving', with 78 occurrences and 24 links, while 'altruism' had 59 occurrences and 30 links.

Besides that, there were three types of 'charitable giving' found in author keywords, namely 'volunteering' (35 occurrences, 21 links), 'blood donation' (10 occurrences, 7 links), and 'corporate philanthropy' (16 occurrences, 5 links). 'Corporate philanthropy' is also linked with author keywords such as 'corporate social responsibility' (25 occurrences, 17 links). As suggested by past researcher, one of the ways for businesses to participate in corporate philanthropy is through corporate social responsibility (CSR). As evidence in Table 1, 'corporate philanthropy' is among the most cited papers when assessing charitable giving such as article by Williams (2003) on 'Women on Corporate Boards of Directors and their Influence on Corporate Philanthropy'.

Several author keywords were also found in conceptualising the 'charitable giving'. For instance, 'charitable giving' is being conceptualised as a subset of behaviour such as 'charitable behaviour' (52 occurrences, 25 links) and 'pro-social behaviour' (49 occurrences, 23 links). Charitable behaviour is a form of pro-social behaviour, such behaviour entails actions that intend to help and do help others (Zhou et al., 2012; Taute and McQuitty, 2004). The term charitable behaviour often used interchangeably with pro-social behaviour and helping behaviour. Bendapudi et al. (1996) early defined helping behaviour as behaviour that intend to improve the wellbeing of the underprivileged, by providing assistance usually with Copyright $\odot$ GLOBAL ACADEMIC EXCELLENCE (M) SDN BHD - All rights reserved 


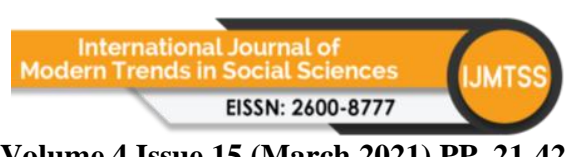

Volume 4 Issue 15 (March 2021) PP. 21-42

DOI 10.35631/IJMTSS.415003

little or no reward in return, while pro-social behaviour is defined as voluntary behaviour that results in benefiting others (Eisenberg and Miller, 1987).

\section{Topic of Interest}

Based on the analysis, the author keyword such as 'charitable organisation' (62 occurrences, 26 links) and 'non-profit organisation' (25 occurrences, 15 links) had a lot of occurrences in relation to charitable giving studies. Considering charitable organisations as an active party in the charitable giving ecosystem, the 'charitable organisation' is the third most occurrences keywords in relation to charitable giving studies.

Having recognized the importance of charitable giving and sophisticated advertising practices in charity advertising (Chang and Lee, 2010), it is important for charitable organizations to understand individual's charitable giving in response to charities' marketing effort such as through fundraising. This argument is supported by the current study analysis, in which 'fundraising' is the fourth most occurrences keywords, with 60 occurrences and 20 links to charitable giving studies.

Besides the occurrences of author keywords at an organisational level, it is essential to understand charitable giving through giver's mind. The bibliometric analysis indicated that there were few antecedents mentioned in the author keyword analysis, which were related to demographic variables such as 'education' (7 occurrences, 7 links) and 'gender differences' (25 occurrences, 17 links). Both keywords have been identified as a strong predictor of charitable giving (e.g., Bekkers and Wiepking, 2011; Einolf, 2011; Croson et al., 2009). This finding is consistent with the analysis in Table 1, where one of the top cited papers mentioned about 'gender differences' when they examined charitable giving, namely 'Gender Differences in the Correlates of Volunteering and Charitable Giving' by Einolf (2011).

The bibliometric analysis revealed that the author keywords were indeed related to the antecedents of charitable giving such as 'religion' (17 occurrences, 16 links) and 'religiosity' (7 occurrences, 3 links). Since most religious faiths also emphasize the importance of caring for the poor and the less unfortunate (Yen and Zampelli, 2014), therefore it is important to understand what drives charitable giving and the roles of religion and religiosity.

There were other few antecedents also mentioned in the author keyword analysis, which were trust ( 9 occurrences, 11 links), generosity ( 6 occurrences, 7 links), motivation ( 5 occurrences, 5 links), social responsibility (5 occurrences, 8 links). For instances, previous research has acknowledged the importance of trust on charitable giving (e.g., Bekkers, 2003; Hager and Hedberg, 2016). The influence of individual's generosity, social responsibility and motivation has also been well recognised by scholars in predicting charitable giving (e.g., Emrich and Pierdzioch, 2015; Kandaurova and Lee, 2019; Hendriks and Peelen, 2013), hence, the occurrences in the author keywords analysis.

Besides that, the analysis of author keywords suggested the essential roles of 'reputation' (8 occurrences, 12 links) in predicting charitable giving. Previous research has investigated the consequences of charity reputation on charitable giving as well as reputation-seeking individuals that influences charitable giving (e.g., Meijer, 2009; Reinstein and Riener, 2012; Peng et al., 2019). For example, non-profit's reputation may influence decision to donate, on the other hand, a person might intend to signal his or her generosity to improve one's reputation through donating. From the author keywords analysis, it can be concluded that Copyright (C) GLOBAL ACADEMIC EXCELLENCE (M) SDN BHD - All rights reserved 


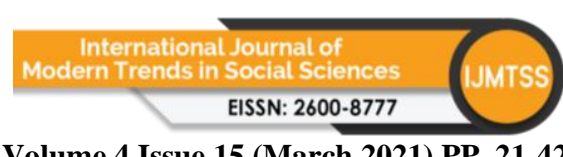

Volume 4 Issue 15 (March 2021) PP. 21-42

DOI 10.35631/IJMTSS.415003

most of prior research focuses on the antecedents of charitable giving, as compared to the consequences of charitable giving. Therefore, future studies are encouraged to investigate the consequences of charitable giving.

Besides marketing and management field, charitable giving studies can be linked to various field including psychology, sociology and economic. The psychological field emphasised on individual personalities, as well as the two psychological motivations such as altruistic and egoistic motives (Sherry, 1983). For example, individuals donate because of intrinsic reasons that can provide psychological benefits or intangible benefits (Bekkers and Wiepking, 2011; Sargeant and Woodliffe, 2007). Based on this argument, the psychological factor is formed, composed of several constructs such as few author keywords identified in this study, namely 'altruism' (59 occurrences, 30 links), 'empathy' (10 occurrences, 10 links) 'happiness' (6 occurrences, 7 links). These keywords could be linked to the psychological determinants of charitable giving.

Accordingly, scholars have also explained charitable giving via sociology approach. The sociological field stresses on the importance of social environment, social norms, and social networks in promoting charitable giving (Schervish and Havens, 1997; Bekkers, 2004). For instances, the analysis of author keywords suggested the following: 'social norms' (13 occurrences, 10 links) and 'social preferences' (10 occurrences, 10 links). These findings are consistent with the analysis in Table 1, where one of the top cited papers mentioned about 'social norms' in relation to charitable giving, namely 'Keeping up with the Joneses: The Relationship of Perceived Descriptive Social Norms, Social Information, and Charitable Giving by Croson, Handy, and Shang (2009).

The economic approach such as the uses of rational choice theory has also been applied in charitable giving studies. This theory suggested that individuals involved in charitable giving due to the benefits ones receive in return such as tax incentives or the 'warm glow' effect (Andreoni, 1990). As suggested by the author keywords analysis, the keyword such as 'incentives' (7 occurrences, 13 links), 'taxation' (5 occurrences, 5 links), and 'warm glow' (10 occurrences, 14 links) were identified. For example, research on individual's charitable giving often associated with the effects of tax incentives on charitable donations (e.g., Fack and Landais, 2010; Almunia et al., 2020).

Besides charitable giving studies being identified in various fields, there was one country mentioned in the author keyword analysis, which were 'United Kingdom' (5 occurrences, 6 links). This is due to the fact that the country has a long philanthropic tradition. According to the World Giving Index 2020, UK is the seventh most generous country in the world. Hence, the occurrences of 'United Kingdom' in the author keywords analysis in relation to charitable giving studies.

In relation to research methodology, there are evidence of an explosion of experimental work, where both laboratory and field experiments were used extensively in investigating charitable giving. For instances, among the 51 author keywords, 'field experiment' (43 occurrences, 22links) and 'experiments' (24 occurrences, 19 links) are the eight and thirteen most occurrences. These findings are consistent with the analysis in Table 1, where two of the top cited papers mentioned about 'field experiment' and 'experiments' when they examined charitable giving, namely 'A Field Experiment on Directed Giving at a Public University by Eckel, Herberich, and Meer (2017) and 'Do People Behave in Experiments as in the Field?' 


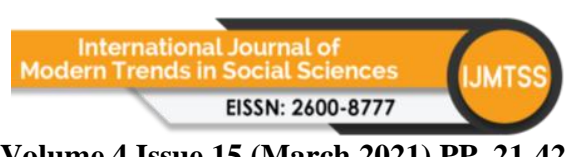

Volume 4 Issue 15 (March 2021) PP. 21-42

DOI 10.35631/IJMTSS.415003

by Benz \& Meier (2008). Based on the current analysis, experimental design is the most frequently used methodology associated with charitable giving studies.

The analysis of author keywords recommended that future research should concentrate on the relationship between agency and charitable giving using experimental design such as laboratory experiment. This is because 'agency' (5 occurrences, 5 links) and 'laboratory experiment' (5 occurrences, 7 links) had become two of the latest author keywords in charitable giving studies (Average Publication Year: 2018 and 2017 respectively). Some studies such as Berman and Smaall (2012) have adopted laboratory experiments to investigate the relationship between agency and charitable giving. This is to examine whether individuals will attain more pleasure from donating when they have the option to choose. Agency is a psychological aspect of charitable behaviour associated to individualism, which is known to enhance the performance of the benefactor, whilst human agency is the ability for a person to decide between options (Heist and Cnaan, 2018). Based on the self-determination theory, Weinstein and Ryan (2010) indicated that those who perceive greater sense of agency while performing charitable activities experience greater well-being outcomes, as a result, better outcomes for the beneficiaries. This is because giving donors more control over their donation increases their perception of agency (Heist and Cnaan, 2018).

However, according to Butera and Houser (2018), the significance role of agency in charitable giving remains largely unexplored. Only recently that few researchers attempted to shed light on this matter by implementing laboratory experiments (e.g., Butera and Houser, 2018; Heist and Cnaan, 2018). Studies conducted by to Butera and Houser (2018) suggested that one of the ways in promoting effective giving is by creating institutions that facilitate delegated generosity. While Heist and Cnaan (2018) experiments results suggested that greater sense of agency leads to even more donations. However, there are still room for future research to continue investigating the effectiveness of agency on charitable giving behaviour and understand the effect of agency in naturally occurring giving markets, as well as in a controlled laboratory setting.

Besides that, the analysis of author keywords suggested that future studies should also concentrate on the role of crowdfunding (8 occurrences, 6 links) and social media (5 occurrences, 5 links) in influencing charitable giving. This is because 'crowdfunding' and 'social media' had become two of the recent author keywords in charitable giving (Average Publication Year: 2016 and 2017 respectively). One of the most cited articles in Table 1 was linked to 'crowdfunding', namely, 'Effects of the Price of Charitable Giving: Evidence from an Online Crowdfunding Platform' by Meer (2014). Charitable crowdfunding is a growing online platform in which fund seekers are requesting for donations from a large group of potential contributors (Liu et al., 2017).

According to Van Wingerden and Ryan (2011), crowdfunding will exceed $\$ 300$ billion in funding operations by 2025 and its growth is exponential in many countries such as the US, UK and Europe countries. With the existing of technology advancement (e.g., the development of Web 2.0) and vast usage of social media, it has been an efficient tool for charities or individuals to raise funds for the needy through crowdfunding platform with the assistance of social media in circulating the campaigns worldwide. Although this trend is prevalent, according to Colombo et al. (2015), research on crowdfunding remains limited. Future studies in relation to Internet-based technologies would be beneficial for the success of charities in supporting charitable causes for the underprivileged. According to SalidoCopyright (C) GLOBAL ACADEMIC EXCELLENCE (M) SDN BHD - All rights reserved 


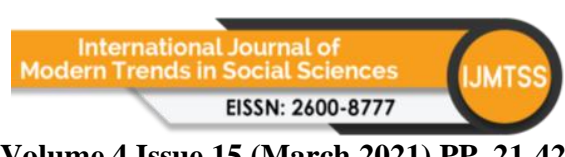

Volume 4 Issue 15 (March 2021) PP. 21-42

DOI 10.35631/IJMTSS.415003

Andres et al. (2020), there is a growth in this area of research as most empirical papers were published from 2015 onward, in which they adopted quantitative methodologies; emphasises on antecedents related to individual giving, organization as main actors, and online channels and design-related features of campaigns as enablers. Nevertheless, based on the authors' systematic review, the effects of donation-based crowdfunding on relevant stakeholders such as beneficiaries and society in general remain largely unknown.

The author keyword such as 'trust' (9 occurrences, 11 links) has also been getting a significant attention in the recent years (Average Publication Year: 2017), especially when there are many charitable organisation, charitable causes, and campaigns throughout the year. Individual donors are left with many options to choose from, which explained the role of trust in charitable giving studies. For example, Taniguchi and Marshall (2014) discussed two types of trust, namely social trust (i.e., trust individual place in anonymous others) and institutional trust (i.e., trust placed in an institution) in relation to charitable giving. Therefore, there are still room for future studies to explore the extensive role of trust in the context of charitable giving.

The analysis of author keywords recommended that future studies should focus on the relationship among social status, social preferences, and charitable giving. This is due to the fact that 'social status' ( 5 occurrences, 6 links) and 'social preferences' (10 occurrences, 10 links) have become two of the recent author keywords in charitable giving studies (Average Publication Year: 2016). Weiss and Fershtman (1998) define social status as 'a ranking of a person or a group of people in each society, based on their traits, assets, and actions'. While social preferences are one type of preference in relation to the concepts of reciprocity, altruism, inequity aversion, and fairness (Fehr and Fischbacher, 2002). Future studies should therefore investigate the various forms of social status and social preferences in influencing charitable giving.

Finally, future studies should emphasize on the role of 'incentives' ( 7 occurrences, 13 links) and 'reciprocity' (8 occurrences, 13 links) as both are the recent authors keywords in relation to charitable giving studies (Average Publication Year: 2016 and 2017 respectively). A major concern in charitable giving studies is related to the concept of reciprocity and incentives (Andre et al., 2017). This is because the notion of pure altruism (e.g., the desire to make others better off) alone cannot be fully accounted for several empirical observations regarding giving behaviour. Alternatively, previous researcher argued that individuals are charitable because they obtain some sort of personal or intrinsic benefit from doing so. In particular, a person might donate in order to receive some intangible rewards such as rewards in the hereafter, self-satisfaction, or avoiding guilt (Jamal et al., 2019), alongside non-monetary utility, or "warm glow" (Andreoni, 1990).

\section{Limitations of Study}

The authors have restricted the search for 'charitable giving' and 'charitable behaviour' to the titles and abstracts, therefore, this study may perhaps leave out selecting articles on 'charitable giving' and 'charitable behaviour' in Scopus database. This is due to the fact that some researchers might not include the keywords of 'charitable giving' and 'charitable behaviour' in their studies and opted for 'helping behaviour' or 'prosocial behaviour' in explaining the altruistic and voluntary act. The findings from this research also suggest future scholars to compare published articles on 'charitable giving' and 'charitable behaviour' from various databases, such as combination of Scopus and Web of Sciences. A more Copyright (C) GLOBAL ACADEMIC EXCELLENCE (M) SDN BHD - All rights reserved 


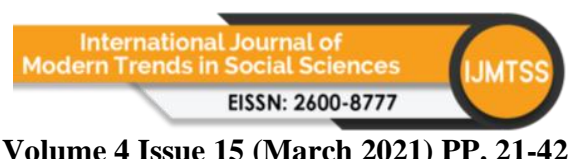

Volume 4 Issue 15 (March 2021) PP. 21-42

DOI 10.35631/IJMTSS.415003

comprehensive bibliometric analysis and results can be achieved from the combination of multiple databases.

\section{Conclusion}

The current study has successfully analysed and discussed the research growth trend of charitable giving based on 1,144 related studies in Scopus database. From the year of 2000 up until now (2020), the growth of charitable giving studies has been increasing rapidly as this topic is known as one of the contributors of giving behaviour, especially in the context of charitable organisations.

Besides that, the bibliometric analysis revealed that the United States and United Kingdom were among the prominent nations in charitable giving studies. Whilst United States was the most affiliated nation in this research area. Other countries such as Iran, Brunei and Bahrain are advised to have international collaboration with top affiliated nations to broaden their research scopes.

It was also discovered that agency, laboratory experiment, crowdfunding, social media, trust, social status, social preferences, incentives, and reciprocity were new area in examining charitable giving with average publication year of 2016 to 2018. These topic areas have the potential to become prominent upcoming topic in the future, hence future researcher should investigate these concepts in relation to charitable giving.

\section{References}

Almunia, M., Guceri, I., Lockwood, B. and Scharf, K. (2020). More giving or more givers? The effects of tax incentives on charitable donations in the UK. Journal of Public Economics, 183, 104-114.

Andreoni, J. (1990). Impure altruism and donations to public goods: A theory of warm glow giving. The economic journal, 100(401), 464-477.

Andreoni, J. and Payne, A.A. (2013). Charitable giving. In Handbook of public economics (Vol. 5, 1-50). Elsevier.

André, K., Bureau, S., Gautier, A. and Rubel, O. (2017). Beyond the opposition between altruism and self-interest: Reciprocal giving in reward-based crowdfunding. Journal of Business Ethics, 146(2), 313-332.

Bekkers, R. (2003). Trust, accreditation, and philanthropy in the Netherlands. Nonprofit and Voluntary Sector Quarterly, 32(4), 596-615.

Bekkers, R. and Wiepking, P. (2011). Who gives? A literature review of predictors of charitable giving part one: Religion, education, age and socialisation. Voluntary Sector Review, 2(3), 337-365.

Bennett, R. (2005). Competitive environment, market orientation, and the use of relational approaches to the marketing of charity beneficiary services. Journal of Services Marketing, 19(7), 453-469.

Benz, M., and Meier, S. (2008). Do people behave in experiments as in the field? - evidence from donations. Experimental economics, 11(3), 268-281.

Bendapudi, N., Singh, S.N. and Bendapudi, V. (1996). Enhancing helping behavior: An integrative framework for promotion planning. Journal of Marketing, 60(3), 33-49.

Berman, J.Z. and Small, D.A. (2012). Self-interest without selfishness: The hedonic benefit of imposed self-interest. Psychological Science, 23(10), 1193-1199.

Bhati, A. and McDonnell, D. (2020). Success in an online giving day: The role of social media in fundraising. Nonprofit and Voluntary Sector Quarterly, 49(1), 74-92. 


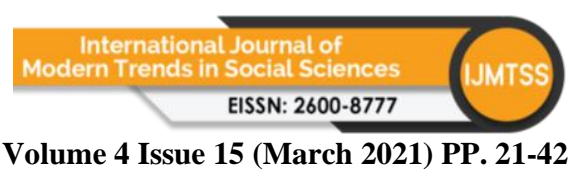

Volume 4 Issue 15 (March 2021) PP. 21-42

DOI 10.35631/IJMTSS.415003

Butera, L. and Houser, D. (2018). Delegating altruism: Toward an understanding of agency in charitable giving. Journal of Economic Behavior \& Organization, 155, 99-109.

Chang, C.T. and Lee, Y.K. (2010). Effects of message framing, vividness congruency and statistical framing on responses to charity advertising. International Journal of Advertising, 29(2), 195-220.

Cobo, M. J., López-Herrera, A. G., Herrera-Viedma, E., and Herrera, F. (2011). Science mapping software tools: Review, analysis, and cooperative study among tools. Journal of the American Society for information Science and Technology, 62(7), 1382-1402.

Colombo, M.G., Franzoni, C. and Rossi-Lamastra, C. (2015). Internal social capital and the attraction of early contributions in crowdfunding. Entrepreneurship theory and practice, 39(1), 75-100.

Croson, R., Handy, F., and Shang, J. (2009). Keeping up with the Joneses: The relationship of perceived descriptive social norms, social information, and charitable giving. Nonprofit Management and Leadership, 19(4), 467-489.

Dean, J. (2020). Student perceptions and experiences of charity on social media: the authenticity of offline networks in online giving. Voluntary Sector Review, 11(1), 4157.

Dreesbach-Bundy, S. and Scheck, B. (2017). Corporate volunteering: A bibliometric analysis from 1990 to 2015. Business Ethics: A European Review, 26(3), 240-256.

Einolf, C. J. (2011). Gender differences in the correlates of volunteering and charitable giving. Nonprofit and Voluntary Sector Quarterly, 40(6), 1092-1112.

Eckel, C. C., and Grossman, P. J. (2003). Rebate versus matching: does how we subsidize charitable contributions matter? Journal of Public Economics, 87(3-4), 681-701.

Eckel, C. C., Herberich, D. H., and Meer, J. (2017). A field experiment on directed giving at a public university. Journal of behavioral and experimental economics, 66, 66-71.

Eisenberg, N. and Miller, P.A. (1987). The relation of empathy to prosocial and related behaviors. Psychological bulletin, 101(1), 91.

Emrich, E. and Pierdzioch, C. (2015). Gender and generosity in charitable giving: Empirical evidence for the German Red Cross. Applied Economics Letters, 22(13), 1041-1045.

Fack, G. and Landais, C. (2010). Are tax incentives for charitable giving efficient? Evidence from France. American Economic Journal: Economic Policy, 2(2), 117-41.

Fehr, E. and Fischbacher, U. (2002). Why social preferences matter-the impact of non-selfish motives on competition, cooperation, and incentives. The economic journal, 112(478), C1-C33.

Hager, M.A. and Hedberg, E.C. (2016). Institutional trust, sector confidence, and charitable giving. Journal of Nonprofit \& Public Sector Marketing, 28(2), 164-184.

Hendriks, M. and Peelen, E. (2013). Personas in action: linking event participation motivation to charitable giving and sports. International Journal of Nonprofit and Voluntary Sector Marketing, 18(1), 60-72.

Heist, H.D. and Cnaan, R.A. (2018). Price and agency effects on charitable giving behavior. Journal of behavioral and experimental economics, 77, 129-138.

Jamal, A., Yaacob, A., Bartikowski, B. and Slater, S. (2019). Motivations to donate: Exploring the role of religiousness in charitable donations. Journal of Business Research, 103, 319-327.

Kandaurova, M. and Lee, S.H.M. (2019). The effects of Virtual Reality (VR) on charitable giving: The role of empathy, guilt, responsibility, and social exclusion. Journal of Business Research, 100, 571-580. 


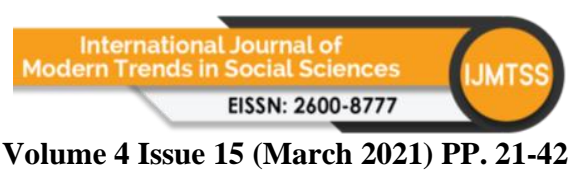

Volume 4 Issue 15 (March 2021) PP. 21-42

DOI 10.35631/IJMTSS.415003

Khudzari, J. M., Kurian, J., Tartakovsky, B., and Raghavan, G. V. (2018). Bibliometric analysis of global research trends on microbial fuel cells using Scopus database. Biochemical engineering journal, 136, 51-60.

Liu, L., Suh, A. and Wagner, C. (2017). Donation behavior in online micro charities: An investigation of charitable crowdfunding projects. In Proceedings of the 50th Hawaii International Conference on System Sciences.

Martínez-Climent, C., Zorio-Grima, A. and Ribeiro-Soriano, D. (2018). Financial return crowdfunding: literature review and bibliometric analysis. International Entrepreneurship and Management Journal, 14(3), 527-553.

Meer, J. (2014). Effects of the price of charitable giving: Evidence from an online crowdfunding platform. Journal of Economic Behavior \& Organization, 103, 113124.

Meijer, M.M. (2009). The effects of charity reputation on charitable giving. Corporate Reputation Review, 12(1), 33-42.

Peng, S., Kim, M. and Deat, F. (2019). The Effects of Nonprofit Reputation on Charitable Giving: A Survey Experiment. VOLUNTAS: International Journal of Voluntary and Nonprofit Organizations, 30(4), 811-827.

Polonsky, M. J., Shelley, L., and Voola, R. (2002). An examination of helping behaviorSome evidence from Australia. Journal of Nonprofit \& Public Sector Marketing, 10(2), 67-82.

Ribar, D.C. and Wilhelm, M.O. (2002). Altruistic and joy-of-giving motivations in charitable behavior. Journal of political Economy, 110(2), 425-457.

Reinstein, D. and Riener, G. (2012). Reputation and influence in charitable giving: an experiment. Theory and decision, 72(2), 221-243.

Salido-Andres, N., Rey-Garcia, M., Alvarez-Gonzalez, L.I. and Vazquez-Casielles, R. (2020). Mapping the field of donation-based crowdfunding for charitable causes: systematic review and conceptual framework. VOLUNTAS: International Journal of Voluntary and Nonprofit Organizations, 1-15.

Sargeant, A. and Woodliffe, L. (2007). Building donor loyalty: The antecedents and role of commitment in the context of charity giving. Journal of Nonprofit \& Public Sector Marketing, 18(2), 47-68.

Schervish, P. G., and Havens, J. J. (1997). Social participation and charitable giving: A multivariate analysis. Voluntas: International Journal of Voluntary and Nonprofit Organizations, 8(3), 235-260.

Supphellen, M., and Nelson, M. R. (2001). Developing, exploring, and validating a typology of private philanthropic decision making. Journal of Economic Psychology, 22(5), 573-603.

Sepulcri, L.M.C.B., Mainardes, E.W. and Belchior, C.C. (2020). Nonprofit branding: a bibliometric analysis. Journal of Product \& Brand Management.

Taute, H. and McQuitty, S. (2004). Feeling good! Doing good! An exploratory look at the impulsive purchase of the social good. Journal of Marketing Theory and Practice, 12(2), 16-27.

Taniguchi, H. and Marshall, G.A. (2014). The effects of social trust and institutional trust on formal volunteering and charitable giving in Japan. VOLUNTAS: International Journal of Voluntary and Nonprofit Organizations, 25(1), 150-175.

Van Eck, N. J., and Waltman, L. (2018). VOSviewer Manual 1.6. 11. Manual, (version 1.6. 9).

Van Wingerden, R. and Ryan, J. (2011). Fighting for funds: An exploratory study into the field of crowdfunding. Extraction, 14(151), 1-082.

Copyright $\odot$ GLOBAL ACADEMIC EXCELLENCE (M) SDN BHD - All rights reserved 
Williams, R. J. (2003). Women on corporate boards of directors and their influence on corporate philanthropy. Journal of Business Ethics, 42(1), 1-10.

Weinstein, N. and Ryan, R.M. (2010). When helping helps, autonomous motivation for prosocial behavior and its influence on well-being for the helper and recipient. Journal of personality and social psychology, 98(2), 222.

Weiss, Y. and Fershtman, C. (1998). Social status and economic performance: A survey. European Economic Review, 42(3-5), 801-820.

Yen, S.T. and Zampelli, E.M. (2014). What drives charitable donations of time and money? The roles of political ideology, religiosity, and involvement. Journal of Behavioral and Experimental Economics, 50, 58-67.

Zupic, I., and Čater, T. (2015). Bibliometric methods in management and organization. Organizational Research Methods, 18(3), 429-472.

Zhang, W., Zhu, Y.C. and Wu, X.L. (2018). A Bibliometric Analysis of Crowdfunding Related Research: Current trends and Future Prospect. In Proceedings of the 3rd International Conference on Crowd Science and Engineering (pp. 1-7).

Zhou, X., Wildschut, T., Sedikides, C., Shi, K., and Feng, C (2012). Nostalgia: The gift that keeps on giving. Journal of Consumer Research, 39(1), 39-50. 